\title{
Relationship between strategic planning and financial performance: The case of small, micro- and medium-scale businesses in the Buffalo City Metropolitan
}

\begin{tabular}{|c|c|}
\hline \multicolumn{2}{|c|}{$\begin{array}{l}\text { Authors: } \\
\text { Shingirai Gomera }{ }^{1} \\
\text { Willie T. Chinyamurindi }^{1} \\
\text { Syden Mishi }\end{array}$} \\
\hline \multicolumn{2}{|c|}{$\begin{array}{l}\text { Affiliations: } \\
{ }^{1} \text { Department of Business } \\
\text { Management, University of } \\
\text { Fort Hare, South Africa }\end{array}$} \\
\hline \multicolumn{2}{|c|}{$\begin{array}{l}{ }^{2} \text { Govan Mbeki Research } \\
\text { and Development Centre, } \\
\text { Department of Economics, } \\
\text { University of Fort Hare, } \\
\text { South Africa }\end{array}$} \\
\hline \multicolumn{2}{|c|}{$\begin{array}{l}\text { Corresponding author: } \\
\text { Willie Chinyamurindi, } \\
\text { wchinyamurindi@ufh.ac.za }\end{array}$} \\
\hline $\begin{array}{l}\text { Dates: } \\
\text { Received: } 24 \mathrm{~J} \\
\text { Accepted: } 19 \mathrm{~L} \\
\text { Published: } 09\end{array}$ & $\begin{array}{l}\text { uly } 2016 \\
\text { Mec. } 2017 \\
\text { May } 2018\end{array}$ \\
\hline \multicolumn{2}{|c|}{$\begin{array}{l}\text { How to cite this article: } \\
\text { Gomera, S., Chinyamurindi, } \\
\text { W.T. \& Mishi, S., 2018, } \\
\text { 'Relationship between } \\
\text { strategic planning and } \\
\text { financial performance: The } \\
\text { case of small, micro- and } \\
\text { medium-scale businesses } \\
\text { in the Buffalo City } \\
\text { Metropolitan', South African } \\
\text { Journal of Economic and } \\
\text { Management Sciences 21(1), } \\
\text { a1634. https://doi.org/ } \\
\text { 10.4102/sajems.v21i1.1634 }\end{array}$} \\
\hline \multicolumn{2}{|c|}{$\begin{array}{l}\text { Copyright: } \\
\text { (c) 2018. The Authors } \\
\text { Licensee: AOSIS. This } \\
\text { is licensed under the } \\
\text { Creative Commons } \\
\text { Attribution License. }\end{array}$} \\
\hline \multicolumn{2}{|l|}{ Read online: } \\
\hline 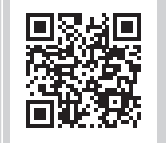 & $\begin{array}{l}\text { Scan this QR } \\
\text { code with your } \\
\text { smart phone or } \\
\text { mobile device } \\
\text { to read online. }\end{array}$ \\
\hline
\end{tabular}

\begin{abstract}
Background: Arguments are made for strategic planning as an important organisational capability used to realise a firm's goals and objectives. Despite this, conflicting views appear to emerge from the extant literature over the link between strategic planning and financial performance. Notably, within a South African context, a few studies have been conducted ascertaining this relationship especially within small, medium and micro-enterprises (SMMEs).

Aim and setting: The study aimed to determine this relationship using survey responses from a sample of 225 respondents classified as owners or managers of SMMEs operating within the Buffalo City Metropolitan in the Eastern Cape Province of South Africa.

Method: Data were analysed through regression and correlation analysis.

Results: Findings reveal strategic planning to have a positive relationship with the financial performance of the SMMEs. Furthermore, aspects of strategic planning (formulation, implementation, evaluation and control) were also found to have a positive relationship with financial performance.

Conclusion: Suggestions for theory and practice are made based on these findings, including how the adoption and usage of strategic planning cannot only be an important organisational capability but also a basis for attaining a competitive advantage within the SMME.
\end{abstract}

\section{Introduction}

South Africa is witnessing a growth in the number of entrepreneurial start-ups (Chinyamurindi 2016). Such start-ups, including the development of entrepreneurial spirit, are encouraged and believed to have ramifications for national growth including economic and social development (Harris, Sapienza \& Bowie 2009). Further, small, medium and micro-enterprises (SMMEs) perform a critical part in developing communities as they comprise a huge workforce and are considered pioneers in implementing fresh concepts (Kuratko 2016). Although SMMEs have been widely acknowledged for their economic and social contribution, the majority of SMMEs perform poorly and, at times, fail in their early stages (Arafat El-Mobayed 2006; Mahembe 2011; Murimbika 2011). However, the key to effectively addressing the problems of poor performance and failure in SMMEs is argued to be the strategic planning process (Arafat El-Mobayed 2006; Odame 2007; Pangarkar 2015). This process is defined as a measured and balanced procedure responsible for giving an organisation an unmistakably distinct drive or aim through a purposefully selected route (Mintzberg 1990).

Within the extant literature, calls exist for more investigations into the concept of strategic planning on outcomes such as organisational performance (Chinyamurindi 2016). Sondari (2014) argues for the need of such research especially within a context of entrepreneurship. Given the global recognition of SMMEs as a driver of growth (Jackson 2015) there is need to continually investigate how strategic planning can contribute to the performance of organisations (Aldehayyat \& Khattab 2013). The purpose of this study is to investigate this relationship within a South African SMME context argued as a potential driver in alleviating poverty and an enabler of economic prosperity (Garwe \& Fatoki 2012; Mahembe 2011). All this despite the risk and high failure rate that characterises it (Pangarkar 2015).

Brewer (2010) highlights that more than three-quarters of business operations in South Africa come from SMMEs, and they also contribute marginally to the gross domestic product (GDP). 
As a means of moving away from the post-apartheid economic system where the economy was dominated by a few parastatals and multinational corporations (Finn, Leibbrandt \& Oosthuizen 2014), priority is placed on SMMEs in South Africa (Garwe \& Fatoki 2012; Mahembe 2011). The support of the South African government to the growth of SMMEs is evident in the creation of a Small Business Development Ministry whose main objective is to govern and provide support to SMMEs (Rustomjee 2015).

\section{Literature review}

\section{Theoretical underpinning Porter's five forces framework}

Porter's five forces examine what distinguishes the competitive environment of an organisation (Grant 2014). Porter's framework is argued to be a possible explanation of how a firm can operate within an industry (Grant \& Jordan 2015). For the organisation, this idea is rather important since the organisation is capable of directing its improvements regarding the selection of tactics and investments (Andersen \& Nielsen 2009). The five forces described by Porter comprise: the threat of new entrants, threat of substitute products, bargaining power of suppliers, bargaining power of customers and competitive rivalry within the industry (Grant 2014). The literature explains that all these five forces are interconnected, and the first four forces all build up to competitive rivalry within the industry (Andalya 2013).

For this investigation, competitive rivalry within the industry is a factor that addresses the majority of the research objectives. The rivalry between organisations controls the desirability of a segment (Grant 2014). Establishments are struggling to uphold their supremacy; therefore, they make strategies to keep them on top (Grant 2014). Rivalry is a game in which, ordinarily, one participant fails at the cost of the other by formulating and implementing better strategies (Andersen \& Nielsen 2009). A move on the part of a participant could result in the other participant creating counter-changes or starting efforts to safeguard themselves from the danger posed by the initial move, hence strategic control and analysis (Grant \& Jordan 2015). In this way, organisations within the same trade are equally dependent, and the manner in which they strategise is shaped by the uncertainty in the environment (Grant 2014). Situations in an industry keep changing based on the actions and reactions of the constituent firms (Gruber et al. 2010). Response to such changes within an industry can mean the difference between success and failure. This places importance on the strategic planning process and its role in making, as argued by Porter (2008), an organisation understand itself within a context and map out a position that is more profitable and less vulnerable to attack. The activities within Porter's framework consist of the traditional strategic management process especially those of environmental scanning, strategy formulation, implementation and evaluation (Porter 2004; Ricks \& Woods 1996).

\section{Resources-based view of the firm}

Further to Porter's framework, this research also embraced the resource-based view (RBV) of the firm (Barney 1991) as a theoretical lens. The RBV links notions from firm economics and strategic management (Grant \& Jordan 2015). In the $\mathrm{RBV}$, the competitive advantage and greater performance of a firm are described by the uniqueness of its abilities (Andersen \& Nielsen 2009). The fundamental suggestion of the resource-based model is that organisations are diverse with regard to the strategic possessions they have and regulate (Grant \& Jordan 2015). Resources make up the major element of investigation for the RBV and can be described as those possessions that are secured partially permanently to the organisation. Traditional foundations of competitive advantage such as monetary and natural resources, equipment and economies of scale can be used to craft value (Gruber et al. 2010).

Capabilities, in contrast, state an organisation's ability to organise and manage diverse resources, commonly in groups, thus making use of a firm's procedures to influence an anticipated goal (Grant \& Jordan 2015). Resources are information-grounded, intrinsically imperceptible procedures that are organisation prescribed and are established over time through multifaceted connections amid the organisation's resources (Grant 2014). Hence, through the definition given on resources and capabilities, the RBV and Porter's framework are not only deemed applicable but linked to this study. Resource contribution rests on the capacity of the human resources to formulate sound strategies (Gruber et al. 2010). More so, the part of dynamic capability factors in the ability of the firm to allocate resources to each section of the strategic planning process. In essence, the RBV, using the seminal contribution of Mahoney and Pandian (1992) seeks to make a link between processes within strategic planning and see how these can be utilised as a basis for competitive advantage. This warrants its use as a theoretical underpinning in this study.

\section{Strategic planning}

Strategic planning can be defined as the procedure of creating and upholding consistency between the establishment's goals and possessions and its shifting prospects (Grant 2014). The strategic planning process, in general, comprises business objectives, a vision, and a clear design to accomplish the idea and achieve the objectives (Dole 2013; Mintzberg 1994). The strategic planning process also entails a scan of the environment (Saunders 2015) and this helps the organisation prepare a suitable action based on this information (GuerrasMartína, Madhokb \& Montoro-Sánchezc 2014). The key constituents of strategic planning practices involve probing questions on where the establishment intends to go, the current situation of the organisation, how the organisation will get there and what alterations or fluctuations will occur in the establishment's environment (Grant \& Jordan 2015; Guerras-Martina et al. 2014). Hutzschenreuter and Kleindienst (2006) view strategic management as a discipline 
where strategic planning is housed. Hence, it can be possible to conclude that research that has supported either the presence of a positive or negative relationship with strategic management implies the same for the strategic planning process (Wijetunga 2013). For this study, strategic planning is considered to consist of: (1) formulation, (2) implementation and (3) strategy control and evaluation. Using the work of Louw and Venter (2006), strategy formulation consists of those steps taken to set the direction of the organisation through analysing the internal and external environment. Conversely, strategic implementation consists of those actions of putting into practice the actions set out as part of strategy formulation. Finally, strategy evaluation and control is a means of making sure that the desired strategy remains on course as per the previous steps.

One of the most important managerial purposes is to measure organisational performance (Sandada, Pooe \& Manilall 2014). Assessing performance, revising variations in the surrounding environment and making alterations are customary and essential parts of the strategic management practice (Guerras-Martina et al. 2014). The means of measuring organisational performance remain an argumentative theme to business consultants and the research fraternity alike (Harris et al. 2009; Sandada et al. 2014). However, some researchers suggest that organisations may use objective measures in contrast to subjective measures to evaluate organisational performance (Mcllquham-Schmidt 2010; Sandada et al. 2014). Financial records comprising an actual return, gross revenue, return on asset, return on capital invested and gross inventory revenue constitute objective measures of financial performance (Mcllquham-Schmidt 2010). On the other hand, subjective measures tend to depend on a manager's or owner's view of organisational performance (Dubilihla \& Sandada 2014).

\section{Strategic planning and financial performance}

A lot of research that looks into the relationship between strategic planning and organisation performance in SMMEs has been conducted over the past decades (Chavunduka, Chimunhu, \& Sifile 2015; Dubilihla \& Sandada 2014; Hakimpoor 2014; Langat \& Auka 2015; Monday et al. 2015; Pangarkar 2015). Study findings by Hakimpoor (2014) suggested that organisations that conducted a strategic planning process performed better than those that had no strategy formulation procedures. Dubilihla and Sandada (2014) revealed that there was a positive relationship between strategic planning and the performance of small business in South Africa. Further, the key to success for small businesses in South Africa was grounded in their ability to practise strategic planning (Dubilihla \& Sandada 2014).

Arasa and K'Obonyo (2012) noted that there is a positive relationship between strategic planning and organisational performance. The two authors further stress that the success and good performance of organisations are centred on how implementation and control and evaluation of the strategic planning process is conducted. Chavunduka et al. (2015) found that there was a positive relationship between strategic planning and organisational performance measures such as net income, return on investment and market share, among others. Monday et al. (2015) acknowledge that organisations with excellent strategy implementation processes had much sounder organisational performance compared to those with a poor or fair strategy implementation process.

\section{Strategy formulation, implementation and evaluation and financial performance}

Concerning the link between aspects of the strategic planning process (such as formulation, implementation and evaluation) and financial performance, mixed results appear to exist. A stream of work appears to suggest that these aspects of the strategic planning process are linked to performance metrics within an organisational setting (e.g. Arabzad et al. 2015). Within a Turkish context, Efendioglu and Karabulut (2010) found a positive correlation to exist between strategic planning (the presence of mission and involvement of top managers) and financial performance. On the other hand, some studies have found a negative relationship to exist between aspects of the strategic planning process and financial performance (Gibson, Cassar \& Wingham 2001). For example, French, Kelly and Harrison's (2004) study on small service businesses revealed that there was also no relationship between these aspects of strategic planning and financial performance. This had been earlier supported within various contexts such as an SMME context (O'Gorman \& Doran 1999) and the service industries such as hospitals in Lebanon (Saleh et al. 2013). These conflicting findings in literature form the basis of this study, hence the hypotheses and research question presented in the following section.

\section{Research question, purpose, hypotheses and conceptual framework}

Based on the extant literature highlighted, there are inconclusive and conflicting results on the relationship between strategic planning and a financial measure of organisational performance. Based on the presented literature review, the following hypotheses are set:

$\mathbf{H}_{\mathbf{1}}$ : There is a significant positive correlation relationship between the strategic planning process and an organisation's financial performance in SMMEs.

$\mathbf{H}_{2}$ : There is a significant positive correlation between the strategy formulation and an organisation's financial performance in SMMEs.

$\mathbf{H}_{3}$ : There is a significant positive correlation between the strategy implementation and an organisation's financial performance in SMMEs.

$\mathbf{H}_{4}$ : There is a significant positive correlation between the strategy evaluation and control and evaluation and an organisation's financial performance in SMMEs.

For this research, strategic planning was considered in the context of the strategic planning process. The primary 


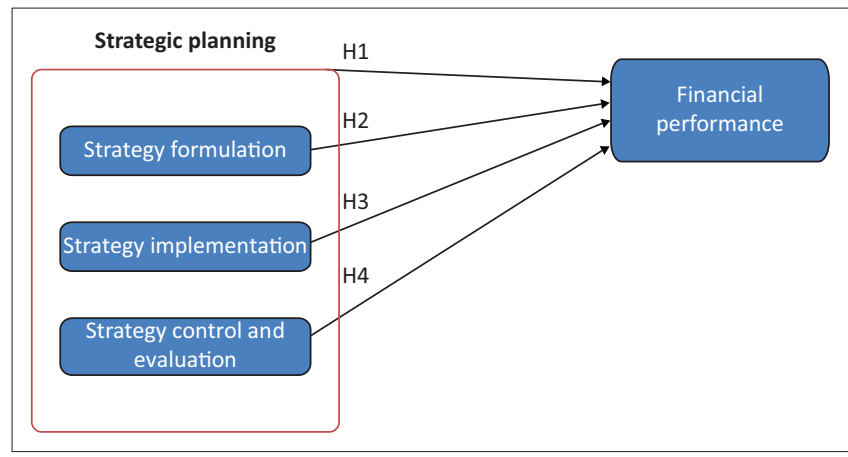

FIGURE 1: Conceptual framework: Hypothesised model of the relationship between strategic planning and financial performance.

objective of this study was to determine the relationship between the strategic planning process and financial measures of organisational performance. The secondary objectives investigated the relationship between the three arms of the strategic planning process (formulation, implementation and control and evaluation) and financial measures of organisational performance. Further, the hypothesised relationships are described graphically in Figure 1. The research sought to answer the following question: what is the relationship between strategic planning and financial performance among a sample of SMMEs operating within the Buffalo City Metropolitan Municipality?

\section{Research methodology \\ Research design}

The study adopted a positivist paradigm using the quantitative research approach to collect data (Creswell 2014). The aim here was to investigate 'cause and effect' (Creswell 2014:23-24) and in the case of the research, the relationship between the independent and dependent variables. Further, the survey research technique using a selfadministered questionnaire was used and, borrowing from Creswell (2014:13), this technique and instrument allowed for the opportunity to understand 'trends, attitudes or opinions' within a subset of a population. Given the research study, questionnaires were also cost-effective, thus allowing for a wider reach (Jack \& Clarke 1998).

\section{Questionnaire design}

Before the questionnaire was administered to the participating SMMEs, a pilot test was conducted to test the questionnaire using a sample of 50 non-participating SMMEs. The purpose of the pilot test was to test the techniques from data collection to analysis that were to be conducted in the main research study. This helped prepare the researchers to prepare for any eventualities that might happen using the pilot study. The research instrument was divided into three sections. The first section consisted of questions about the SMME's background and these included: (1) the industry category, (2) age of the firm, (3) the firm capital size in rand value, (4) the characteristics of the person or team responsible for strategic planning and (5) questions about the nature of strategic planning. The second section consisted of questions about how strategic planning occurs and was adapted from previous studies (Arafat El-Mobayed 2006) and measured on a 5-point Likert scale (strongly disagree to strongly agree). This section consisted of scales measuring (1) the organisation's mission (4 items), (2) the organisation's objectives (4 items), (3) strategy formulation (12 items), (4) strategy implementation (2 items) and, finally, (5) strategy control (7 items). The third section of the questionnaire measured financial performance and was also adopted from previous studies (Green \& Medlin 2003). Each of the performance-related items asked the owner, manager or CEO to highlight their organisation's performance in comparison to the industry average on a 5-point Likert scale anchored between 'weaker' (1) and 'stronger' (5) (Green \& Mediln 2003).

\section{Population and sample data collection}

The total number of registered SMMEs operating within the Buffalo City Metropolitan Municipality central district was 515 based on information supplied by the Eastern Cape Development Corporation (ECDC). From this and using the Raosoft sample size calculator (Raosoft Inc 2017), a total of 221 SMMEs were recommended as a sample. Using a convenience sampling approach, a total of 225 SMMEs took part in the study based on issues such as accessibility (Wiid \& Diggines 2015). Given that the SMMEs were within the vicinity of the Buffalo City Metropolitan Municipality, a selfadministered questionnaire was dropped off at the relevant companies for the attention of the owner, manager or CEO of the SMME. After a week, a follow-up visit, email inquiry or telephone call was made to arrange for collection of the questionnaire. Based on the analysis, the participating SMMEs were split as follows: (1) manufacturing $(n=44$, $20 \%)$, (2) construction $(n=34,15 \%)$, (3) wholesale $(n=40$, $18 \%)$, (4) agriculture $(n=20,9 \%)$, (5) service $(n=52,23 \%)$ and, finally, (6) other $(n=35,16 \%)$.

\section{Data analysis}

The Statistical Package of the Social Sciences program (SPSS) version 22.0 was used to analyse the data collected in this study. Cronbach's alpha coefficients $(\alpha)$ were used to assess the internal consistency of the measuring instruments (Clark \& Watson 1995). Further, statistical analysis also involved generating a descriptive picture concerning the phenomena under study. Inferential statistics helped determine the association between the dependent and the independent variables (Wiid \& Diggines 2015). Inferential statistics further help to come to conclusions based on observations on the population of the study (Babbie \& Mouton 2002). In achieving the aims of this study, correlation and regression analyses were used (Wiid \& Diggines 2015).

Assessing the internal reliability of a research instrument is very important to ensure the reliability of information gathered by the researcher (Cooper \& Schindler 2006). The Cronbach's alpha coefficients of the dependent and 
independent variables were computed using SPSS. The evidence from Table 1 indicates that all the scales used in this study met the set standard of 0.70 , as guided by the literature (Nunnally 1978). Thus, the entire questionnaire with its scales had an acceptable level of reliability. The results of the analysis are tabulated in Table 1.

\section{Results \\ Descriptive statistics results}

This section provides an overview of the results on the background information section of the questionnaire. The respondents were asked questions about the history of their organisations. Table 2 summarises the findings of the descriptive results. Based on this analysis, the majority of SMMEs had been operating for 1-3 years with a frequency

TABLE 1: Cronbach's alpha coefficients.

\begin{tabular}{lc}
\hline Scale & Cronbach's alpha coefficients \\
\hline Firm mission & 0.946 \\
Firm objectives and goals & 0.884 \\
Strategy formulation & 0.909 \\
Strategy implementation & 0.662 \\
Strategy control and evaluation & 0.890 \\
Organisational financial measure & 0.944 \\
\hline
\end{tabular}

TABLE 2: Descriptive results $(n=225)$.

\begin{tabular}{llc}
\hline Variable & \multicolumn{1}{c}{ Range } & Frequency (\%) \\
\hline Age of the SMME & 1-3 years & 27.2 \\
& $4-6$ years & 25 \\
& & 5 \\
& 7-9 years & 21.4 \\
& Over 10 years & 26.3 \\
Use of strategic plans & Yes & 76 \\
Duration of strategic plans & No & 24 \\
& Less than a year & 28 \\
& 1-3 years & 32 \\
& More than 4 years & 16 \\
& Did not respond & 24 \\
\hline
\end{tabular}

SMME, Small-, medium- and micro-enterprises. of $27.2 \%$, followed by those entities with over 10 years of operation with a frequency of $26.3 \%$. Concerning strategic plans, the majority of SMMEs (76\%) used strategic plans with only $24 \%$ citing having no strategic plans. Finally, concerning the duration of strategic plans, 32\% of the SMMEs cited having plans that span 1-3 years and 28\% indicated their plans cover less than a year. From this analysis, 16\% of SMMEs cited having plans that cover a duration of more than 4 years and $24 \%$ did not respond to the question.

\section{Correlation analysis between variables}

The results in Table 3 indicate that there is a correlation between the variables under study. The researcher made use of correlation as a statistical measure since correlation best describes the strength and direction of a linear relationship between two variables (Graham 2009). Moreover, the correlation coefficient is a statistical measure of the strength of a monotonic relationship between paired data (Pallant 2010). Strategy formulation and financial performance were found to have the highest correlation and significance at 0.629. The second highest correlation and significance occurs between strategy implementation and financial performance which is at 0.615. Strategy control and evaluation recorded the lowest correlation and significance with a result of 0.608 . Therefore, due to the results obtained in the correlation analysis, the study found a correlation to exist between strategic planning (consisting of formulation, implementation, as well as control and evaluation) and the dependent variable (financial performance).

\section{Regression analysis tests}

The results of the regression analyses are summarised in Table $4 \mathrm{a}$ and $4 \mathrm{~b}$. The researcher made use of regression analysis as a statistical test since regression describes the strength and direction of the relationship between two variables, and it goes further by providing many refined examinations of the inter-relationships among groups of

TABLE 3: Correlation results.

\begin{tabular}{|c|c|c|c|c|c|}
\hline Variables & Category & Formulation & Implementation & Control and evaluation & Financial performance \\
\hline \multirow[t]{3}{*}{ Formulation } & Pearson correlation & 1 & - & - & $0.629 *$ \\
\hline & Sig. (two-tailed) & - & - & - & 0.000 \\
\hline & Number (respondents) & 224 & - & - & 224 \\
\hline \multirow[t]{3}{*}{ Financial performance } & Pearson correlation & $0.629 *$ & - & - & 1 \\
\hline & Sig. (two-tailed) & 0.000 & - & - & - \\
\hline & Number (respondents) & 224 & - & - & 224 \\
\hline \multirow{2}{*}{ Implementation } & Sig. (two-tailed) & - & - & - & 0.000 \\
\hline & Number (respondents) & - & 224 & - & 224 \\
\hline \multirow[t]{3}{*}{ Financial performance } & Pearson correlation & - & $0.615^{*}$ & - & 1 \\
\hline & Sig. (two-tailed) & - & 0.000 & - & - \\
\hline & Number (respondents) & - & 224 & - & 224 \\
\hline \multirow[t]{2}{*}{ Control and evaluation } & Pearson correlation & - & - & 1 & $0.608^{*}$ \\
\hline & Sig. (two-tailed) & - & - & - & 0.000 \\
\hline \multirow[t]{3}{*}{ Financial performance } & Pearson correlation & - & - & $0.608 *$ & 1 \\
\hline & Sig. (two-tailed) & - & - & 0.000 & - \\
\hline & Number (respondents) & - & - & 224 & 224 \\
\hline
\end{tabular}

*, Significant at $5 \%$ 
TABLE 4a: Regression analysis results: Model summary.

\begin{tabular}{lcccc}
\hline Model name & $\boldsymbol{R}$ & $\boldsymbol{R}$-squared & Adjusted R-squared & $\begin{array}{c}\text { Standard error of } \\
\text { the estimate }\end{array}$ \\
\hline 1 & 0.795 & 0.632 & 0.615 & 4.484 \\
\hline
\end{tabular}

TABLE 4b: Regression analysis results: Analysis of variance

\begin{tabular}{lccccc}
\hline Model 1 & Sum of squares & $d \boldsymbol{f}$ & Mean squares & $\boldsymbol{f}$ & Significance \\
\hline Regression & 5579.183 & 3 & 1859.728 & 67.397 & $0.000^{*}$ \\
Residual & 6070.563 & 220 & 27.593 & - & - \\
\hline Total & 11649.746 & 223 & - & - & - \\
\hline
\end{tabular}

*, Significant at $5 \%$

Note: Predictors that are constant: Firm mission, firm objectives and goals, control and evaluation, implementation, formulation, firm capital size, age of firm, duration of strategic plan, written strategic plan; Dependent variable: Organisational financial performance.

variables (Graham 2009). This technique is most suitable when investigating the relationship between one independent variable and a number of dependent variables (Neuman 2003). The R-squared value of 0.632 (63\%) explains the model concerning the relationship between strategic planning and financial performance. Furthermore, the analysis of variance certifies the applicability of the model and that it can be recognised as statistically significant.

Table $4 \mathrm{a}$ and $4 \mathrm{~b}$ illustrate how the factors in the regression model presented in Table 3 influence the prediction of organisational, financial performance. Four of the ten factors in this regression analysis model can be regarded as statistically significant predictors to the model equation. The results from the model show that the question of whether or not an organisation has a written strategic plan has the largest beta coefficient value of 0.633 , thus making it the largest predictor of financial performance. The period covered by the organisation's strategic plan is shown as the second highest predictor with a beta coefficient of 0.306 , thus indicating that the greater the number of years covered by the strategy, the greater the organisation's financial performance. The third contributing factor to the prediction of financial performance was the organisational mission which had a beta coefficient of 0.225. Lastly, the firm's capital size was the fourth predictor contributing to financial performance with a beta coefficient of -0.157 . The negative beta coefficient obtained from a firm's capital size indicates that the factor influenced financial performance negatively. Thus, the larger the capital size, the worse the organisation performs financially.

\section{Discussion, implications, limitations and future study Discussion}

The main purpose of the study was to establish the relationship between the strategic planning process and organisational performance in SMMEs in the Buffalo City Municipality. The results of the study on the relationship between strategic planning processes and financial performance in SMMEs indicated a positive relationship to exist among the SMMEs sampled. The findings on the relationship between strategic planning and organisational performance are consistent with the work of Dubilihla and Sandada (2014). Further, the findings of this work that showed that the strategic planning process has a positive effect on financial performance are also similar to findings reported in a study conducted by Monday et al. (2015).

The findings of this current study revealed that there was a positive relationship between strategy formulation and organisational, financial performance in SMMEs. The results of this study are similar to some previous investigations available in the literature (e.g. Andalya 2013; Chavunduka et al. 2014; Monday et al. 2015; Wijetunga 2013). Furthermore, the results of this study support findings of Wijetunga (2013) and Andalya (2013) which showed that there was a positive relationship between strategy formulation and the performance of manufacturing SMMEs and commercial banks, respectively.

Furthermore, this study was set to answer the question on the relationship between strategy implementation and financial performance in SMMEs in the Buffalo City Municipality. Strategy implementation was found to have a positive relationship with organisational, financial performance among the sampled SMMEs in the Buffalo City Municipality. The results of this study are similar to some previous investigations available in the literature (e.g. Andalya 2013; Langat \& Auka 2015; Monday et al. 2015; Pangarkar 2015; Wijetunga 2013). Langat and Auka's (2015) study produced results that showed a positive relationship between strategy implementation and corporate performance. These findings were also similar to previous research (e.g. Pangarkar 2015).

Lastly, based on the evidence provided by this current study, strategy control and evaluation was found to have a positive relationship with organisational performance among the sampled SMMEs in the Buffalo City Municipality. The results of this study are similar to some previous investigations available in the literature (e.g. Chavunduka et al. 2014; Dubilihla \& Sandada 2014; Langat \& Auka 2015; Monday et al. 2015; Pangarkar 2015). The current study's findings are in line with those of Hakimpoor (2014) who established that organisations that used the strategy control and evaluation had a better chance of performing well than those that did not use strategy control and evaluation. Similar findings were also reported in a study done by Monday et al. (2015) that put forward that there is a positive relationship between strategy control and evaluation and organisational, financial performance in manufacturing companies in Nigeria.

Based on the evidence provided in this study and a thorough review of literature (e.g. Chavunduka et al. 2014; Dubilihla \& Sandada 2014; Hakimpoor 2014; Langat \& Auka 2015; Monday et al. 2015; Pangarkar 2015), the study comes to the conclusion that the strategic planning process (strategy formulation, strategy implementation, strategy control and evaluation) is of great importance to how organisations perform. Moreover, the evidence provides an answer to the 
gap that the researcher identified in the literature on the relationship of the four factors (strategic planning process, strategy formulation, strategy implementation, strategy control and evaluation) against financial performance.

\section{Implications}

The most important contribution of this study is that it helps to extend knowledge and understanding on the issues of the relationship between the strategic planning process and organisational performance in SMMEs (Chavunduka et al. 2014; Dubilihla \& Sandada 2014; Hakimpoor 2014; Monday et al. 2015). The research magnified the frame of information in the area of strategic planning about performance of SMMEs. It makes available more literature that looks into these two variables (strategic planning process and financial performance in SMMEs) in an African context. This work advances an understanding of phenomena that are not often researched outside the Western and Asian contexts. This study is one of the few that have been conducted in subSaharan Africa that look into the relationship between the strategic planning process and organisational performance in SMMEs (Chavunduka et al. 2014; Dubilihla \& Sandada 2014). The current research showed that there was evidence that the strategic planning process has a positive effect on organisational performance in SMMEs.

Methodologically, the quantitative approach offered an opportunity for a valuable examination of the study's variables grounded on the information gathered, along with respondents answering questions posed to them in answering the objectives of the study (Creswell 2014). The objective of the research was to be able to generalise about a specific population based on the results of a representative sample of that population. Further, the quantitative research approach provided a platform for understanding the phenomena better.

Based on the results of this study, the researcher concludes that the strategic planning process has a positive impact on organisational performance in SMMEs. Since the impact of the strategic planning process is positive, it is a good predictor of organisational performance. Therefore, this study contributes to shedding light on how important the strategic planning process is and how much attention has to be committed by those responsible for strategic planning in SMME organisations. There is a need for SMME organisations to provide their employees with training programmes that would develop their abilities and skills to understand and make use of the plans provided by top management. Training programmes should not only be provided to subordinates but also to the owners and managers to improve their ability to come up with sound and fruitful strategic plans. Furthermore, SMMEs need to integrate with organisations of higher learning in providing quality training and guidance on the use and importance of strategic planning in business organisations.

It is advisable for SMME managers and owners to employ strategic planning experts or create a department responsible for the strategic planning in the organisational structure to improve and advance the strategic planning process. Having a strategic planning manager or department will allow diverse integration of ideas between members of the strategic planning department or managers with the owner of the SMME.

Technology has greatly advanced in the past decade, and this has brought great improvement in how people and organisations perform their day-to-day business. Therefore, the use of new technology and computerised software may also improve how SMME organisations strategically plan. Use of specialised computer software in strategic planning aids in simplification and enabling this process, which may result in sound strategic planning and good organisational performance.

\section{Limitations}

The major limitation of this research is that the researcher only focused on data collection in one region. Restricting data collection to Buffalo City Metropolitan Municipality in the Eastern Cape Province of South Africa limits the generalisation of the findings of this study. Hence, having considered data collection from different regions would have made the findings more generalisable. Secondly, the research only considered a single respondent in an organisation in the form of the SMME owner or manager, thus ignoring other members of the organisation. Having considered more respondents from an organisation would have provided better clarity on the information about the organisations. Moreover, there are high chances of respondents responding to the questions in the questionnaire in a socially desirable way. Thus, respondents may acknowledge the presence of strategic planning only because it is socially expected of them to do so, thus making the data collected unreliable.

\section{Future research}

Repeated investigations can help deliver comparative interpretations of measures in a variety of settings in an industrial, national and international context. The current study had its sample drawn from one centralised location, in the Buffalo City Metropolitan Municipality in the Eastern Cape Province of South Africa. Therefore it is advised that studies are conducted with respondents drawn from different provinces in South Africa and other regions on the African continent. This may be a possible platform in advancing understanding on the role of strategic planning in organisations. Apart from exclusively being grounded on the objective or performance approach, future investigations could be grounded on other various hypothetical approaches such as stakeholders, competitive value and environmental turbulence to offer an all-inclusive viewpoint of how these variables help SMMEs plan for their performance, success and successions.

This study only considered the strategic planning process (formulation, implementation and evaluation and control) 
as the independent variable and financial performance as the dependent variable. There is need to conduct studies that will widen the range of independent variables and integrate factors such as gender and level of education of owners or managers, location and size of the SMMEs into the investigation. Furthermore, there is need to integrate the non-financial measures of performance into such a study.

\section{Acknowledgements}

The research was funded by the Govan Mbeki Research Development Centre at the University of Fort Hare.

\section{Competing interests}

The authors declare that they have no financial or personal relationships that may have inappropriately influenced them in writing this article.

\section{Author's contributions}

S.G. collected the data and wrote up the initial draft. W.T.C. supervised S.G. for his master's studies and was involved in the write-up of drafts of this paper. S.M. assisted with the statistical analysis of the data.

\section{References}

Aldehayyat, J.S. \& Al Khattab, A.A. 2013, 'Strategic planning and organizational effectiveness in Jordanian hotels', International Journal of Business and Management 8(1), 11-25.

Andalya, C.K., 2013, 'Impact of strategic planning on organizational performance: A case study of equator flower farm in Eldoret East District, Kenya', master's thesis, Kenyatta University, Kenya.

Andersen, T.J. \& Nielsen, B.B., 2009, 'Adaptive strategy making: The effects of emergent and intended strategy modes', European Management Review 6(2), 94-107. https://doi.org/10.1057/emr.2009.7

Arabzad, S.M., Ghorbani, M., Razmi, J. \& Shirouyehzad, H., 2015, 'Employing fuzzy TOPSIS and SWOT for supplier selection and order allocation problem', The International Journal of Advanced Manufacturing Technology 76(5), 803-818. https://doi.org/10.1007/s00170-014-6288-3

Arafat El-Mobayed, M.G., 2006, 'The relationship between strategic planning and growth in small industrial businesses in Palestine case study: The Gaza Strip', master's thesis, The Islamic University - Gaza, Deanery of Graduate Studies, Gaza Strip, Palestine.

Arasa, R. \& K'obonyo, P., 2012, 'The relationship between strategic planning and firm performance', International Journal of Humanities and Social Science, Specia Issue 2(22), 201-213.

Babbie, E. \& Mouton, J.J., 2002, The practice of social research, Oxford University Press, Oxford.

Barney, J., 1991, 'Firm resources \& sustained competitive advantage', Journal of Management 17(1), 99-120. https://doi.org/10.1177/014920639101700108

Brewer, J.P., 2010, Sustainability of South African FMCG SMME retail businesses in Cape Peninsula, Cape Peninsula University of Technology, Cape Town.

Chavunduka, D., Chimunhu, P. \& Sifile, O., 2015, 'Strategic planning intensity and firm performance: A case of Zimbabwe mining development corporation', European Journal of Business and Management 7(5), 201-222.

Chinyamurindi, W.T., 2016, 'A narrative investigation on the motivation to become an entrepreneur amongst a sample of Black entrepreneurs in South Africa: Implications for entrepreneurship career development education', Acta Commerci 16(1), 1-9. https://doi.org/10.4102/ac.v16i1.310

Clark, L. \& Watson, D. 1995, 'Constructing validity basic issues in objective scale development', Psychological Assessment 7, 309-319.

Cooper, D.R. \& Schindler, P.S., 2006, Business research methods, McGraw-Hill, New York.

Creswell, J.W., 2014, Research design, Sage Publications, Thousand Oaks, CA.

Dole, W., 2013, 'Strategic planning and assessment: Pigs of the same sow?', The Journal of Library Administration 53, 283-292. https://doi.org/10.1080/0193082 6.2013.865397

Dubilihla, J. \& Sandada, M., 2014, 'Impact of strategic planning on small and mediumsized enterprises' (SMEs) performance: The role of employee participation, implementation incentives and evaluation and control', Journal
Efendioglu, A.M. \& Karabulut, A.T., 2010, 'Impact of strategic planning on financial performance of companies in Turkey', International Journal of Business and Management 5(4), 3-12. https://doi.org/10.5539/ijbm.v5n4p3

Finn, A., Leibbrandt, M. \& Oosthuizen, M., 2014, 'Poverty, inequality, and prices in postapartheid South Africa', WIDER Working Paper 2014/127, UNU-WIDER, Helsinki.

French, S.J., Kelly, S.J. \& Harrison, J.L., 2004, 'The role of strategic planning in the performance of small, professional service firms - A research note', Journal of Management Development 23 (9), 765-776. https://doi.org/10.1108/ 02621710410549611

Garwe, D. \& Fatoki, O., 2012, 'The impact of gender on SME characteristics and access to debt finance in South Africa', Development Southern Africa 29(3), 448-461. https://doi.org/10.1080/0376835X.2012.706040

Gibson, B., Cassar, G. \& Wingham, D., 2001, 'Longitudinal analysis of relationships between planning and performance in small Australian firms', Proceedings of the USASBE/SBIDA Annual National Conference, Orlando, FL, February 7-10, 2001 pp. 1-22.

Graham, J.W., 2009, 'Missing data analysis: Making it work in the real world', Annual Review of Psychology 60, 549-576. https://doi.org/10.1146/annurev.psych. 58.110405.085530

Grant, M. R., 2014, Contemporary strategic management, 6th edn., Wiley, West Sussex. Grant, M. R. \& Jordan, J.J., 2015, Foundations of strategy, 2nd edn., Wiley, West Sussex. Green, K.W. Jr \& Medlin, B., 2003, 'The strategic planning process: the link between mission statement and performance', Academy of Strategic Management Journa 2(1), 23-32.

Gruber, M., Heinemann, F., Brettel, M. \& Hungeling, S., 2010, 'Configurations of resources and capabilities and their performance implications: An exploratory study on technology ventures', Strategic Management Journal 31(12), 13371356. https://doi.org/10.1002/smj.865

Guerras-Martína, L.A., Madhokb, A. \& Montoro-Sánchezc, A., 2014, 'The evolution of strategic management research: Recent trends and current directions', $B R Q$ Business Research Quarterly 17(2), 69-76. https://doi.org/10.1016/j.brq 2014.03.001

Hakimpoor, H., 2014, 'Strategic planning process dimensions and SMEs performance', Proceedings of 10th Global Business and Social Science Research Conference, Beijing, China, June 23-24, 2014, n.p.

Harris, J.D., Sapienza, H.J. \& Bowie, N.E., 2009, 'Ethics and entrepreneurship', Journal of Business Venturing 24(5), 407-418. https://doi.org/10.1016/j.jbusvent.2009. 06.001

Hutzschenreuter, T. \& Kleindienst, I., 2006, 'Strategy-process research: What have we learned and what is still to be explored', Journal of Management 32,673-720. https://doi.org/10.1177/0149206306291485

Jack, B. \& Clarke, A.M., 1998, 'The purpose and use of questionnaires in research', Professional Nurse 14(3), 176-179.

Jackson, A.J., 2015, 'Can strategic management techniques be applied to small and medium enterprises?' Social Science Research Network, viewed 13 January 2014 from http://works.bepress.com/anthony_jackson/11/

Kuratko, D.F., 2016, Entrepreneurship: Theory process and practice, Cengage Learning, Boston, MA.

Langat, C.J. \& Auka, O.D., 2015, 'Effects of strategic planning on performance of medium sized enterprises in Nakuru town', Journal of Business Administration and Management Sciences Research 4(2), 49-59.

Louw, L. \& Venter, P. 2006, Strategic management: Winning in the Southern African workplace, Oxford University Press, Cape Town.

Mahembe, E., 2011, Literature review on small and medium enterprises access to credit and support in South Africa, Underhill Corporate Solutions, Pretoria.

Mahoney, J. \& Pandian, J., 1992, 'The resource-based view within the conversation of strategic management', Strategic Management Journal 13(5), 363-380.

Mcllquham-Schmidt, A., 2010, Strategic planning and corporate performance: What is the relationship?, working paper 02, Department of Management and the relationship?, working paper 2 , Department of Management and http://www.hha.dk/man/cmsdocs/WP/2010/wp2010_02.pdf

Mintzberg, H., 1990, 'The design school: Reconsidering the basic premises of strategic management', Strategic Management Journal 11(3), 171-195. https://doi.org/ management', Strategic

Mintzberg, H., 1994, The rise and fall of strategic planning: Reconceiving roles for planning, plans, planners, Free Press, New York.

Monday, J.U., Akinola, G.O., Ologbenla. P. \& Aladeraji, O.K., 2015, 'Strategic management and firm performance: A study of selected manufacturing companies in Nigeria', European Journal of Business and Management 7(2), 161-171.

Murimbika, M., 2011, 'Influence of strategic management practices on the entrepreneurial orientation of South African firms in the financial and business services sectors', master's dissertation, University of Witwatersrand Johannesburg, South Africa.

Neuman, L.W., 2003, Social research methods: Qualitative \& quantitative approaches, 5 th edn., Pearson Education, Boston, MA.

Nunnally, J.C., 1978, Psychometric theory, 2nd edn., McGraw-Hill, New York.

Odame, A.M., 2007, 'The relevance of strategic planning for entrepreneurial businesses in South Africa', master's thesis, University of Pretoria, Pretoria, South Africa.

O'gorman, C. \& Doran, R., 1999, 'Mission statements in small and medium-sizes business', Journal of Small Business Management 37(4), 59-68.

Pallant, J., 2010, SPSS survival manual, 4th edn., Allen \& Unwin Book Publishers, Australia. 
Pangarkar, N., 2015, 'Performance implications of strategic changes: An integrative framework', Business Horizons 58, 295-304. https://doi.org/10.1016/j.bushor. 2015.01.003

Porter, M.E., 2004, Competitive advantage: Creating and sustaining superior performance, Free Press, New York.

Porter, M.E., 2008, 'The five competitive forces that shape strategy', Harvard Business Review 86(1), 78-93.

Ricks, D. \& Woods, T., 1996, 'Strategic planning for improved competitiveness by regional commodity industries', Journal of Food Distribution Research 27(1), 59-71.

Raosoft, 2017, Raosoft sample size calculator, Raosoft, Inc., Seattle, WA, available from http://www.raosoft.com/samplesize.html

Rustomjee, Z., 2015, Infrastructure in South Africa, OECD Economics Department Working Papers, OECD Publishing, Paris.

Saleh, S., Kaissi, A., Seamaan, A. \& Natafgi, N.M., 2013, 'Strategic planning processes and financial performance among hospitals in Lebanon', International Journal of Health Planning Management 28(1), 34-45. https://doi.org/10.1002/hpm.2128
Sandada, M., Pooe, D. \& Manilall, D., 2014, 'Strategic planning and its relationship with business performance among small and medium enterprises in South Africa', International Business \& Economics Research Journal 13(3), 167-183. https://doi. org/10.19030/iber.v13i3.8602

Saunders, L., 2015, 'Academic libraries' strategic plans: Top trends and underrecognized areas', The Journal of Academic Librarianship, 41, 285-291. https:// doi.org/10.1016/j.acalib.2015.03.011

Sondari, M.C., 2014, 'Is entrepreneurship education really needed: Examining the antecedent of entrepreneurial career intention?', Procedia - Socia and Behavioural Sciences 115, 44-53. https://doi.org/10.1016/j.sbspro.2014. 02.414

Wiid, J. \& Diggines, C., 2015, Marketing research, 3rd edn., Juta and Company, Cape Town.

Wijetunga, W.A.D.S., 2013, 'The relationship between strategic planning and business performance: An empirical study of manufacturing SMEs in western province in Sri Lanka', master's thesis, University of Sri Jayewardenepura, Sri Jayewardenepura, Sri Lanka. 